\title{
Uji aktivitas antibakteri ekstrak etanol daun sungkai (Peronema canescens Jack) terhadap pertumbuhan Escherichia coli dengan metode difusi cakram Kirby-Bauer
}

\author{
D. Fransisca ${ }^{1 *}$, D. N. Kahanjak ${ }^{1}$, A. Frethernety ${ }^{2}$ \\ ${ }^{1}$ Departemen Fisiologi Kedokteran, Universitas Palangka Raya, Kalimantan Tengah, Indonesia \\ 2Departemen Farmakologi, Fakultas Kedokteran, Universitas Palangka Raya, Kalimantan Tengah, Indonesia
}

\begin{abstract}
Abstrak.
Penyakit diare adalah suatu kondisi serius dan berbahaya, yang salah satu penyebabnya adalah bakteri Escherichia coli. Sungkai merupakan tanaman yang dengan mudah ditemukan di Indonesia, khususnya Kalimantan Tengah. Daun muda sungkai digunakan sebagai obat tradisional dan berpotensi sebagai antibakteri. Tujuan penelitian untuk mengetahui pengaruh aktivitas antibakteri dari ekstrak etanol daun sungkai (Peronema canescens Jack) dalam menghambat pertumbuhan $E$. coli, yang diamati dengan metode cakram Kirby-Bauer. Post-test only control group design adalah metode yang dipakai pada penelitian ini. Kadar ekstrak etanol daun sungkai ( $P$. canescens) yang diujikan adalah 25\%, 50\%, 75\% dan 100\%. Hasil penelitian menunjukkan bahwa pertumbuhan E. coli dapat dihambat dengan ekstrak etanol daun sungkai ( $P$. canescens) dengan konsentrasi $25 \%, 50 \%$, 75\% dan $100 \%$, yang dibuktikan dengan adanya zona hambat sebesar 3,75mm, 3,5 mm, 3,5 $\mathrm{mm}$ dan $7,75 \mathrm{~mm}$ pada masing-masing konsentrasi secara berurutan, dengan konsentrasi efektif sebesar 25\%. Kesimpulan penelitian adalah ekstrak etanol daun sungkai (P. canescens) dapat menghambat pertumbuhan $E$. coli. Pengembangan penelitian perlu dilakukan lebih jauh untuk mengetahui kadar minimum yang diperlukan untuk mendapatkan aktivitas antibakteri ekstrak sungkai.
\end{abstract}

\begin{abstract}
.
Diarrhea is a serious and dangerous condition that could be caused by Escherichia coli. Sungkai is a plant that easily could be found in Indonesia, especially in Central Borneo. The young leaf of sungkai usually used as traditional medicine and potentially as an antibacterial. Aim of this study was to determine the antibacterial activity from the ethanol extract of sungkai (Peronema canescens Jack) leaf to inhibit the growth of E. coli, examined by Kirby-Bauer's disc method. Post-test only control group design was the method used in this study. The ethanol extract of sungkai (P. canescens) leaf was tested with various concentration $(25 \%, 50 \%, 75 \%$ and $100 \%)$. The results showed that the E. coli's growth could be inhibited by ethanol extract of sungkai (P. canescens) leaf with a concentration of $25 \%, 50 \%, 75 \%$ and $100 \%$, proved by 3,75 $\mathrm{mm}, 3,5 \mathrm{~mm}, 3,5 \mathrm{~mm}$ and 7,75 $\mathrm{mm}$ inhibition zone in each of concentration sequentially, with the effective concentration of $25 \%$. It is concluded that the ethanol extract of sungkai ( $P$. canescens) leaf could inhibit the growth of E. coli. Further research should be developed to determine the minimum levels needed to obtain the antibacterial activity of sungkai extract.
\end{abstract}

Keywords: E. coli, kirby-bauer, sungkai, inhibition zone

Kata kunci: E. coli, kirby-bauer, sungkai, zona hambat

\section{PENDAHULUAN}

Data WHO (2013) menunjukkan bahwa setidaknya satu balita meninggal karena diare per detiknya. Riset kesehatan dasar tahun 2013 memperlihatkan angka kejadian diare adalah 3,5\%, sementara di Kalimantan Tengah sekitar 2,6\% (Balitbangkes Kemenkes 2013). Diare dapat terjadi karena adanya infeksi dari bakteri, virus, parasit dan jamur. Penyebab diare kedua terbanyak adalah Escherichia coli yang termasuk dalam famili Enterobacteriacceae. E. coli adalah bakteri batang dan bakteri gram negatif yang habitat alaminya berada di dalam saluran cerna manusia dan juga hewan (Brooks et al. 2010; Zhou et al. 2018). E. coli termasuk ke dalam bakteri gram negatif dengan ukuran 0,4-0,7 mikron

\footnotetext{
* Korespondensi Penulis

Email : destaryadi@gmail.com
} 
tanpa spora, berbentuk batang pendek dan bergerak dengan flagel peritrik. Perbedaan sifat virulensi dan strain yang berbeda menyebabkan mekanisme yang berbeda. Secara umum mekanisme diare yang disebabkan oleh E. coli adalah dengan melakukan pelekatan di epitel sel usus besar atau usus halus yang disandi oleh gen pada plasmid (Brooks et al. 2010).

Sungkai (Paronema canescens Jack) merupakan tanaman yang sejatinya adalah tumbuhan liar, namun karena tumbuhan ini bernilai ekonomis, banyak masyarakat membudidayakannya. Biasanya tanaman sungkai dapat dijumpai di hutan, kebun, maupun halaman. Sungkai dapat tumbuh dengan mudah dan tidak perlu perawatan khusus, sehingga tanaman ini juga digunakan sebagai pembatas atau pagar hidup pekarangan rumah (Ningsih 2013; Yanarita et al. 2014)

Tanaman sungkai termasuk ke dalam tanaman kayu-kayuan yang diameternya mencapai $60 \mathrm{~cm}$ yang mampu tumbuh hingga setinggi 20-30 m dan memiliki batang bebas cabang sekitar $15 \mathrm{~m}$. Batang sungkai berwarna abu-abu atau sawo matang dengan bentuk yang lurus berlekuk kecil, beralur dangkal terkelupas kecil dan tipis. Penampang kulit luar batangnya memiliki warna kekuningan, merah muda, hingga coklat. Kayunya berteras (inti kayu atau bagian tengah kayu) dengan warna sawo muda. Bulu-bulu halus tersebar pada ranting dan anak daun bagian bawah. Daun bersirip ganjil dan majemuk yang terletak berpasangan atau berselang serta lancip pada ujung daunnya. Letak bunga berpasangan dengan kedudukan malai dan buahnya kecil-kecil. Perakarannya menyebar dangkal dan tidak tahan terhadap kekurangan zat asam lebih dari sepuluh hari (Ningsih 2013).

Tanaman sungkai ( $P$. canescens) dapat tumbuh dengan baik pada ketinggian 0-600 mdpl pada cuaca tropis dengan rata-rata curah hujan tahunan 2100-2700 mm. Penanaman pohon sungkai memerlukan tanah dengan kandungan unsur hara yang baik dan tidak dianjurkan dilakukan pada tanah yang terbentuk antara batuan kapur pasir yang bercampur dengan tanah liat, yang kadar airnya rendah atau dikenal dengan tanah mergel, karena tanaman akan menjadi layu dan kering.

Daun muda tanaman sungkai dari suku verbenaceae, secara tradisional sering digunakan sebagai obat pilek, obat cacingan (ringworms), pencegah sakit gigi dengan cara berkumur, campuran rempah di air mandi bagi wanita yang baru saja melahirkan dan sebagai penurun panas. Daun muda yang digunakan direbus, kemudian air rebusan dikonsumsi (Ningsih 2013). Pemanfaatan tanaman sungkai oleh suku Dayak Kalimantan disebabkan oleh kebiasaan dan faktor terjangkaunya bahan, karena tumbuhan ini banyak ditemui di Kalimantan. Banyaknya pemanfaatan tanaman ini tidak diiringi dengan pengetahuan tentang khasiatnya oleh masyarakat suku Dayak Kalimantan secara luas, sehingga efek dan manfaatnya bagi kesehatan perlu menjadi perhatian. 
Penelitian ini bertujuan untuk mengetahui pengaruh antibakteri dari ekstrak etanol daun sungkai ( $P$. canescens) dalam menghambat pertumbuhan $E$. coli dengan menggunakan metode pengujian cakram Kirby-Bauer.

\section{METODOLOGI}

Tumbuhan yang digunakan pada penelitian ini adalah sungkai (Peronema canescens Jack). Metode penelitian adalah metode cakram Kirby-Bauer. Metode ini merupakan metode yang sederhana dan mudah dilakukan untuk menentukan aktivitas anti mikroba, yakni dengan mengamati zona hambat yang terbentuk pada uji cakram. Keunggulan metode ini adalah fleksibilitas yang lebih besar dalam memilih obat antibiotik tertentu yang diperiksa (SHCM 2013).

Peneliti mengendalikan semua variabel luar yang memberikan pengaruh selama berlangsungnya eksperimen, jenis penelitian seperti ini disebut sebagai penelitian experimental. Peneliti membagi sampel menjadi dua kelompok, kelompok pertama diperlakukan sebagai kelompok eksperimen dan kelompok lainnya diperlakukan sebagai kelompok kontrol. Kedua kelompok ini diuji pada akhir penelitian (post-test) (Sastroasmoro dan Ismael 2011). Kelompok eksperimen terdiri dari perlakuan ekstrak daun sungkai dengan konsentrasi 25\%, 50\%, 75\% dan 100\%, sedangkan kelompok kontrol terdiri dari kontrol negatif dan positif.

Setelah dilakukan pengukuran, data dianalisis menggunakan One Way Anova yang bertujuan untuk mengetahui suatu hubungan atau pengaruh dengan membandingkan lebih dari dua kelompok perlakuan berbeda. Selain itu, digunakan juga uji MIC (Minimum Inhibitory Concentration) untuk melihat konsentrasi hambat minimum pada pertumbuhan bakteri sesudah dilakukan inkubasi selama 18 sampai 24 jam (Balouiri 2015).

\subsection{Lokasi kajian dan waktu penelitian}

Pengambilan sampel dilakukan secara acak pada tumbuhan sungkai yang tumbuh di daerah Kuala Kurun, Kabupaten Gunung Mas. Tumbuhan yang diteliti merupakan tumbuhan yang dibibit dan diberikan perawatan berkala di daerah kebun sungkai. Penelitian dilakukan di Laboratorium Penelitian Universitas Muhammadiyah, Palangka Raya. Uji determinasi terhadap tumbuhan yang digunakan dilakukan di Laboratorium Taksonomi Tumbuhan, Fakultas Biologi, Universitas Jenderal Soedirman. Pengujian kandungan dari daun sungkai dilakukan di Laboratorium Pendidikan Kimia, Universitas Palangka Raya.

\subsection{Prosedur penelitian dan analisis data}

Penelitian ini menggunakan daun sungkai seberat $6 \mathrm{~kg}$. Daun sungkai sebagai sampel uji penelitian terlebih dahulu diuji kandungan zat aktifnya. 
Selanjutnya, daun sungkai diolah menjadi serbuk, lalu diayak dengan ayakan nomor 60 mesh menjadi serbuk simplisia dan dimaserasi. Hasil dari maserasi adalah cairan filtrat yang dikumpulkan dari beberapa kali proses maserasi hingga filtrat tidak berwarna, sebanyak $5200 \mathrm{ml}$. Cairan filtrat yang terkumpul disatukan dan diuapkan dengan waterbath pada suhu $84^{\circ} \mathrm{C}$ selama kurang lebih 17 jam, hasilnya diperoleh ekstrak kental sebesar 62 gram. Setelah ekstrak diperoleh, ekstrak dibuat dalam berbagai konsentrasi yaitu 25\%, 50\%, 75\%, $100 \%$ dengan pelarut etanol 96\% (Yani and Putranto 2014). Pemilihan konsentrasi ini dibuat berdasarkan pembagian sederhana, karena peneliti membuat konsentrasi tertinggi adalah $100 \%$ dan kemudian diturunkan konsentrasinya dengan perbandingan.

Koloni E. coli yang ditumbuhkan pada cawan petri berisi Muller Hinton Agar (MHA) diberikan perlakuan dengan meletakan kertas cakram Kirby-Bauer yang sebelumnya sudah direndam dalam ekstrak daun sungkai selama 15 menit dan kemudian diinkubasi selama 24 jam pada suhu $37^{\circ} \mathrm{C}$. Setelah 24 jam inkubasi, diameter zona hambat yang terbentuk pada tiap konsentrasi dan pengulangannya masing-masing dihitung dan dijumlahkan, kemudian dibagi sesuai dengan banyaknya pengulangan untuk menentukan nilai rerata zona hambat untuk tiap konsentrasi.

Data dianalisis dengan menggunakan One Way Anova. Metode ini dipilih karena kelompok perlakuan lebih dari dua buah (penelitian ini menggunakan 6 perlakuan dengan masing-masing sebanyak 4 kali pengulangan, total 24 sampel). Apabila data menyebar normal, maka dianalisis untuk validitas data dengan Post-Hoc. Hipotesis dinyatakan diterima apabila nilai $p<0,05$ (Aedi 2010; Sastroasmoro dan Ismael 2011; Dahlan 2013).

\section{HASIL DAN PEMBAHASAN}

\subsection{Hasil}

Pada penelitian ini, dilakukan analisis kandungan zat aktif dalam daun sungkai sebelum dibuat menjadi ekstrak. Hasil uji kandungan zat aktif pada daun sungkai disajikan pada Tabel 1. Senyawa daun sungkai yang tertera pada hasil uji dalam Tabel 1 tersebut merupakan antibakteri.

Setelah diidentifikasi kandungan antibakteri pada daun sungkai, dilakukan ekstraksi dan percobaan untuk menilai zona hambat. Gambar 1 menunjukkan bahwa zona hambatan tertinggi diperoleh pada konsentrasi ekstrak daun sungkai $100 \%$, sedangkan yang terendah pada konsentrasi $25 \%$. Ekstrak sungkai memiliki kemampuan sebagai antibakteri dibuktikan dengan terbentuknya zona hambat pada pertumbuhan E. coli. Hal ini sesuai dengan hipotesis pada penelitian ini yang menyatakan bahwa ekstrak etanol daun sungkai dapat menghambat pertumbuhan E. coli. 
Tabel 1. Hasil identifikasi kandungan daun sungkai.

\begin{tabular}{|c|c|c|c|}
\hline Uji & Identifikasi & Hasil & Keterangan \\
\hline Alkaloid & $\begin{array}{l}\text { Lapisan heksana + asam nitrat } \\
\text { pekat + asam sulfat }\end{array}$ & Terbentuk warna kuning & +++ \\
\hline Steroid & $\begin{array}{l}\text { Lapisan heksana + asam } \\
\text { asetat anhidrat + asam sulfat }\end{array}$ & Terbentuk warna hijau & ++ \\
\hline Terpenoid & Lapisan heksana + asam sulfat & Tidak terbentuk warna merah & - \\
\hline Flavonoid & $\begin{array}{l}\text { Lapisan etanol + serbuk logam } \\
\mathrm{Mg}+\mathrm{HCl}\end{array}$ & Tidak terbentuk warna oranye & - \\
\hline Fenolik/Tanin & Lapisan etanol $+\mathrm{FeCl}_{3}$ & Terbentuk cincin warna hijau & +++ \\
\hline Saponin & Lapisan etanol (dikocok kuat) & Terbentuk busa & + \\
\hline $\begin{aligned} \text { Keterangan : } & +++ \\
& ++ \\
& + \\
& -\end{aligned}$ & $\begin{array}{l}\text { : Banyak } \\
\text { : Sedang } \\
\text { : Sedikit } \\
\text { : Tidak ada }\end{array}$ & & \\
\hline
\end{tabular}

Gambar 1. Zona hambat terbesar yang terbentuk (kiri) dan zona hambat terkecil yang terbentuk (-).

Jangka sorong digunakan untuk mengukur zona hambat yang terbentuk dari beberapa perlakuan konsentrasi ekstrak etanol daun sungkai. Pengukuran dilakukan terhadap diameter zona hambatan di sekeliling tiap disc (Kourmouli et al. 2018). Pengukuran yang dilakukan adalah mengamati dan mengukur diameter zona hambat yang terbentuk di sekeliling paper disc menggunakan jangka sorong, lalu hasil pengukuran dikurangi dengan diameter paper disc yaitu $6 \mathrm{~mm}$ dari setiap pengukuran (Novaryatiin et al. 2018). Hasil pengukuran zona hambat menunjukkan bahwa ekstrak etanol daun sungkai (P. Canescens) yang diuji dalam berbagai konsentrasi $(25 \%, 50 \%, 75 \%$ dan 100\%), mampu membentuk diameter zona hambat pada pertumbuhan E. coli. Secara lengkap, hasil pengukuran zona hambat pada setiap konsentrasi disajikan pada Tabel 2. Rata-rata zona hambat beserta standar deviasi dari masing-masing konsentrasi juga digambarkan dalam bentuk grafik pada Gambar 2. 
Tabel 2. Hasil pengukuran zona hambat pada pertumbuhan E. coli yang diberikan ekstrak etanol daun sungkai (P. canescens) menggunakan metode Kirby-Bauer.

\begin{tabular}{ccccccc}
\hline \multirow{3}{*}{ Pengulangan } & \multicolumn{5}{c}{ Diameter zona hambat (mm) } \\
\cline { 2 - 5 } & \multicolumn{5}{c}{ Konsentrasi ekstrak etanol } & \\
& daun sungkai (Peronema canescens Jack) & Kontrol (+) & Kontrol (-) \\
\cline { 2 - 5 } & $25 \%$ & $50 \%$ & $75 \%$ & $100 \%$ & & \\
\hline 1 & 2 & 3 & 4 & 8 & 38 & 0 \\
2 & 3 & 3 & 4 & 10 & 37 & 0 \\
3 & 4 & 4 & 3 & 7 & 37 & 0 \\
4 & 6 & 4 & 3 & 6 & 39 & 0 \\
Mean & 3,75 & 3,5 & 3,5 & 7,75 & 38 & - \\
\hline
\end{tabular}

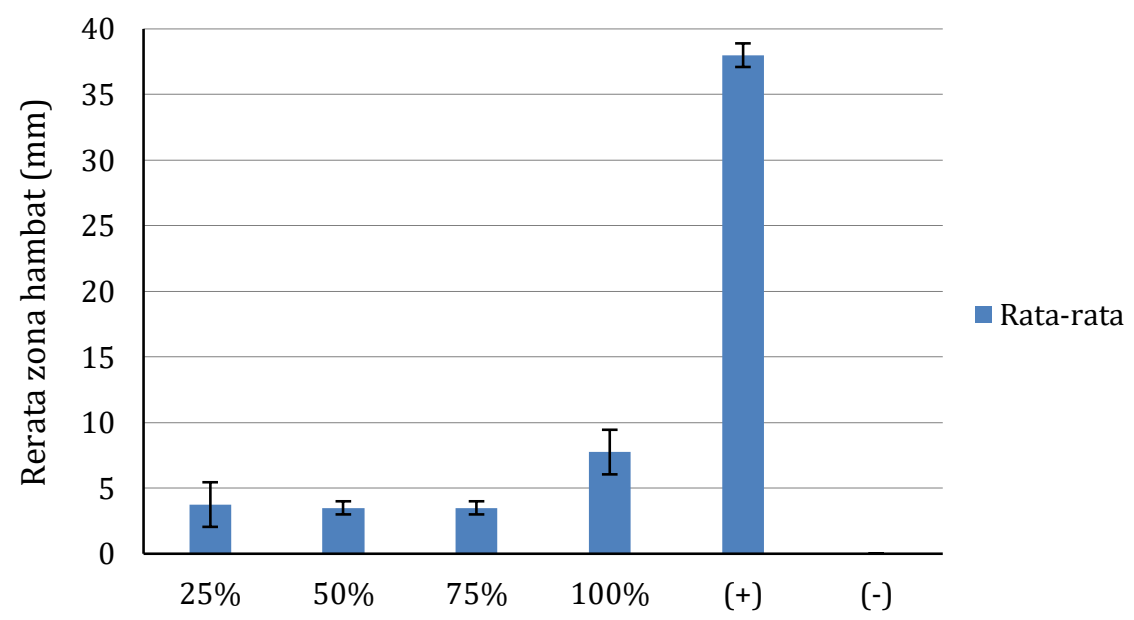

Gambar 2. Rata-rata diameter zona hambat.

Hasil ukur diameter zona hambat dianalisis lebih lanjut untuk mengetahui apakah data yang dimiliki telah terdistribusi normal atau tidak. Pada penelitian ini jumlah sampel yang digunakan kurang dari 30, oleh karena itu uji ShapiroWilk merupakan pengujian yang lebih sensitif untuk menilai normalitas distribusi data. Hasil uji normalitas ditampilkan pada Tabel 3.

Tabel 3. Hasil uji normalitas data menggunakan Shapiro-Wilk (jumlah data $<50$ ).

\begin{tabular}{lccc}
\hline & Statistic & $\mathrm{df}$ & Significance \\
\hline Zona hambat ekstrak daun sungkai & 0,855 & 16 & 0,016 \\
\hline
\end{tabular}

Tabel 3 memperlihatkan bahwa diameter zona hambat pada E. coli memiliki nilai signifikan yaitu 0,016 yang berarti nilai ini >0,05, sehingga distribusi data dinyatakan normal. Karena data dinyatakan terdistribusi normal, selanjutnya dilakukan Uji varians data untuk memenuhi syarat One Way Anova. Pengujian terhadap varians data pada penelitian ini menggunakan uji Levene. Hasil uji varians data menunjukkan bahwa nilai signifikan yaitu 0,342 yang 
berarti nilai ini >0,05 (Tabel 4). Berdasarkan hipotesis pada pengujian varians data dalam penelitian ini, hipotesis yang diterima adalah $\mathrm{H}_{0}$ atau dengan kata lain data tersebut memiliki varians yang sama.

Tabel 4. Uji varians data.

\begin{tabular}{cccc}
\hline Levene Statistic & $\mathrm{df} 1$ & $\mathrm{df} 2$ & Significance \\
\hline 1,227 & 3 & 12 & 0,342 \\
\hline
\end{tabular}

Tabel 5 memperlihatkan nilai signifikan dari uji One Way Anova yaitu 0,001 yang berarti $\mathrm{H}_{1}$ diterima atau terdapat perbedaan rata-rata antar kelompok konsentrasi pada penelitian ini. Untuk mengetahui pada kelompok mana terdapat perbedaan tersebut, maka dilakukan analisis selanjutnya yaitu uji Post-Hoc. Hasil uji Post-Hoc menunjukkan adanya perbedaan atau selisih yang signifikan dari masing-masing kelompok data terhadap kelompok data lainnya (Tabel 6). Namun demikian, ada pula yang tidak memiliki perbedaan signifikan. Kelompok data konsentrasi 25\% terhadap kelompok 50\% dan 75\% tidak berbeda signifikan, sedangkan kelompok data konsentrasi $100 \%$ terhadap kelompok data konsentrasi lainnya memiliki perbedaan yang signifikan. Terlihat pada Tabel 6, nilai rerata masing-masing konsentrasi memiliki perbedaan yang sangat signifikan (hingga mencapai angka 4) saat dibandingkan dengan nilai rerata konsentrasi $100 \%$. Data memiliki perbedaan yang signifikan apabila nilai signifikannya $<0,05$.

Tabel 5. Hasil uji One Way Anova.

\begin{tabular}{lc}
\hline Uji One Way Anova & Significance \\
\hline Kelompok perlakuan ekstrak etanol daun sungkai* & 0,001 \\
\hline Keterangan: *konsentrasi. &
\end{tabular}

Tabel 6. Perbandingan masing-masing kelompok perlakuan (konsentrasi) dengan uji Post-Hoc.

\begin{tabular}{ccrr}
\hline \multirow{2}{*}{ Konsentrasi (I) } & Konsentrasi (J) & Perbedaan rata-rata (I-J) & Significance \\
\hline \multirow{2}{*}{$25 \%$} & $50 \%$ & 0,250 & 0,795 \\
& $75 \%$ & 0,000 & 1,000 \\
& $100 \%$ & $-4,500^{*}$ & $0,000^{*}$ \\
\hline \multirow{2}{*}{$50 \%$} & $25 \%$ & $-0,250$ & 0,795 \\
& $75 \%$ & $-0,250$ & 0,795 \\
$75 \%$ & $100 \%$ & $-4,750^{*}$ & $0,000^{*}$ \\
& $25 \%$ & 0,000 & 1,000 \\
& $50 \%$ & 0,250 & 0,795 \\
$100 \%$ & $100 \%$ & $-4,500^{*}$ & $0,000^{*}$ \\
& $25 \%$ & $4,500^{*}$ & $0,000^{*}$ \\
& $50 \%$ & $4,750^{*}$ & $0,000^{*}$ \\
& $75 \%$ & $4,500^{*}$ & $0,000^{*}$ \\
\hline
\end{tabular}

Keterangan: *terdapat perbedaan rata-rata yang signifikan. 


\subsection{Pembahasan}

Kontrol negatif yang menggunakan DMSO tidak memperlihatkan adanya zona hambat. DMSO dapat digunakan sebagai pengencer larutan dan tidak berpengaruh terhadap aktivitas antibakteri. Dengan demikian aktivitas inhibisi dapat dipastikan berasal dari ekstrak tumbuhan yang digunakan, bukan dari pengencer yang dipakai (Rachmawati et al. 2014).

Hasil penelitian menunjukkan bahwa dalam konsentrasi 25\% masih didapatkan zona hambat meskipun minimum. Dengan kata lain, konsentrasi 25\% pada penelitian ini merupakan MIC (Minimum Inhibitory Concentration), karena konsentrasi tersebut merupakan konsentrasi terendah yang memberikan aktivitas antibakteri dalam penelitian ini, dibuktikan dengan adanya zona hambat pada sekeliling cakram.

Zona hambat yang lebih besar dapat terlihat pada konsentrasi $100 \%$ dibandingkan dengan yang terbentuk pada konsentrasi $75 \%, 50 \%$ dan $25 \%$. Besar zona hambat yang terbentuk berbanding lurus dengan tingginya konsentrasi ekstrak yang digunakan, hal ini berarti bahwa aktivitas antibakteri juga semakin tinggi. Hasil tersebut sesuai dengan penelitian Arum et al. (2012), daya hambat terhadap bakteri semakin besar seiring bertambah tingginya konsentrasi sebuah ekstrak, karena dalam konsentrasi ekstrak yang semakin tinggi maka bahan aktif antibakteri yang terkandung juga semakin banyak. Penambahan konsentrasi senyawa antibakteri juga diduga memperkuat penetrasi senyawa antibakteri yang berpotensi untuk merusak sistem metabolisme sel dan menyebabkan kematian sel hingga ke bagian dalam sel mikroba (Ningtyas 2010).

Semakin lama proses inkubasi, maka diameter zona hambatnya akan semakin luas. Hal ini karena senyawa aktif yang ada di dalam ekstrak tersebut akan semakin meningkat dan memberikan zona hambat yang semakin luas seiring bertambah lamanya inkubasi. Namun, selanjutnya kecepatan pembentukan zona hambat akan melambat karena ekstrak akan mengalami penurunan jumlah kandungan senyawa aktif. Hal yang melambat hanya terjadi pada kecepatan pembentukan zona hambatnya saja (Hidayat et al. 2013).

Terbentuknya zona hambat pada setiap konsentrasi merupakan akibat dari senyawa aktif yang dimiliki oleh daun sungkai seperti flavonoid, saponin dan tanin. Kandungan-kandungan tersebut memiliki aktivitas yang dapat digunakan sebagai antibakteri (Ningsih 2013; Kusriani 2014; Yani and Putranto 2014). Membran sel bakteri dirusak dan dihancurkan keutuhannya oleh flavonoid dengan pembentukan senyawa kompleks baru terhadap protein ekstrasel, sehingga membran sel yang rusak tersebut tidak bisa diperbaiki kembali (Ningsih 2013). Fungsi saponin sebagai antibakteri adalah bekerja dengan merusak porin di membran luar dinding sel bakteri, dengan cara membentuk 
sebuah ikatan polimer kuat. Pertumbuhan bakteri terhambat atau mati akibat rusaknya porin sebagai jembatan untuk jalan keluar masuknya senyawa, sehingga menyebabkan krisis nutrisi pada sel bakteri (Ningsih 2013). Tanin sebagai antibakteri menggagalkan pembentukan sel bakteri dengan menghalau kerja dari DNA topoisomerase dan reverse transcriptase enzyme. Adhesi sel mikroba dihambat, enzim dinonaktifkan dan pada lapisan dalam sel transpor protein dikacaukan. Dinding sel terbentuk tidak sempurna, karena polipeptida yang dimiliki oleh dinding sel dirusak, sehingga sel bakteri menjadi lisis dan mati karena adanya tekanan osmotik dan fisik (Moh Syafiq 2013; Pang et al. 2014).

\section{KESIMPULAN DAN SARAN \\ 4.1. Kesimpulan}

Pertumbuhan E. coli dapat dihambat dengan aktivitas antibakteri yang dimiliki oleh ekstrak etanol daun sungkai ( $P$. canescens). Konsentrasi $25 \%$ merupakan konsentrasi efektif ekstrak etanol daun sungkai dalam menghambat pertumbuhan E. coli, terlihat dari zona bening yang terbentuk di sekitar kertas cakram dengan diameter sebesar 3,75 $\mathrm{mm}$.

\subsection{Saran}

Penelitian berikutnya diharapkan dapat terus berkembang dengan mengoreksi kekurangan-kekurangan yang ada selama proses penelitian ini. Kekurangan yang dimaksud seperti keterbatasan alat dan bahan pendukung penelitian, waktu inkubasi yang cukup singkat, hingga pembagian konsentrasi yang tergolong sederhana untuk mengetahui sebuah konsentrasi hambat minimal. Saran pengembangan penelitian pada bagian pembuatan ekstrak adalah memperbaharui peralatan dan metode yang lebih modern untuk memperoleh hasil yang maksimal. Disarankan untuk melakukan penelitian lanjutan dengan mempertimbangkan penggunaan konsentrasi yang lebih rendah dari konsentrasi terendah pada penelitian ini untuk memastikan MIC (Minimum inhibitory concentration) pada ekstrak daun sungkai. Selain itu, disarankan pula untuk melakukan penelitian kandungan daun sungkai secara kuantitatif agar dapat membandingkan kandungan sungkai yang tumbuh di Kalimantan dengan luar Kalimantan.

\section{DAFTAR PUSTAKA}

Aedi N. 2010. Pengolahan dan analisis data hasil penelitian. Universitas Pendidikan Indonesia. Bandung.

Arum YP, Supartono dan Sudarmin. 2012. Isolasi dan uji daya antimikroba ekstrak daun kersen (Muntingia calabura). Jurnal MIPA 35(2):165-174. 
[Balitbangkes Kemenkes] Badan Penelitian dan Pengembangan Kesehatan Kementerian Kesehatan. 2013. Riset kesehatan dasar. Balitbangkes Kemenkes. Jakarta.

Balouiri M. 2015. Methods for in vitro evaluating antimicrobial activity: A review. Journal of Pharmaceutical 6(2016):71-79.

Brooks GF, Carroll KC, Butel JS, Morse SA dan Mietzner TA. 2010. Mikrobiologi kedokteran (Jawetz, Melnick, \& Adelberg) edisi 25. EGC. Jakarta.

Dahlan MS. 2013. Statistik untuk kedokteran dan kesehatan edisi 5. Salemba Medika. Jakarta.

Hidayat MN, Hifiza A dan Asmar I. 2013. Uji daya hambat ramuan herbal (bawang putih, daun sirih dan kayu manis) terhadap pertumbuhan Bacillus subtilis dan Escherichia coli. Jurnal Ilmu dan Industri Peternakan 1(1):13-23.

Kourmouli A, Valenti M, van Rijn E, Beaumont HJE, Kalantzi OI, Schmidt-Ott A and Biskos G. 2018. Can disc diffusion susceptibility test assess the antimicrobial activity of engineered nanoparticles?. J Nanopart Res. 20(3):62.

Kusriani. 2014. Uji aktivitas antibakteri ekstrak dan fraksi kulit batang dan daun sungkai (Peronema Canescens Jack) terhadap Staphylococcus aureus. Jurnal Farmasi Galenika 2(1):4-6.

Moh Syafiq A. 2013. Efektivitas antibakteri biji pepaya (Carica papaya Linn) terhadap bakteri Staphylococcus aureus, Escherichia coli dan Pseudomonas aeruginosa secara in vitro [Skripsi]. Universitas Muhammadiyah Semarang. Semarang.

Ningsih A. 2013. Potensi antimikroba dan analisis spektroskopi isolat aktif ekstrak n-heksan daun sungkai (Peronema canescens.Jack) terhadap beberapa mikroba uji [Tesis]. Pascasarjana Program Studi Farmasi, Universitas Hasanudin. Makassar.

Ningtyas R. 2010. Uji antioksidan, antibakteri ekstrak air daun kecombrang (Etlingera elatior (Jack) R.M.Smith) sebagai pengawet alami terhadap Escherichia coli dan Staphylococcus aureus [Skripsi]. Program Studi Biologi, Fakultas Sains dan Teknologi, Universitas Islam Negri Syarif Hidayatullah. Jakarta.

Novaryatiin S, Handayani R dan Chairunnisa R. 2018. Uji daya hambat ekstrak etanol umbi hati tanah (Angiotepris Sp.) terhadap bakteri Staphylococcus aureus. Jurnal Surya Medika 3(2):23-31.

Pang Y, Wang D, Fan Z, Chen X, Yu F, Hu X, Wang K and Yuan L. 2014. Blumea balsamifera-a phytochemical and pharmacological review. Molecules 19(7):9453-9477.

Rachmawati F, Nuria CM dan Sumantri. 2014. Uji aktivitas antibakteri fraksi kloroform ekstrak etanol pegagan (Centella asiatica (L) Urb) serta 
identifikasi senyawa aktifnya [Prosiding]. Prosiding Seminar Nasional Peranan dan Kontribusi Herbal dalam Terapi Penyakit Degeneratif 7-13.

Sastroasmoro S dan Ismael S. 2011. Dasar-dasar metodologi penelitian klinis edisi ke-4. CV. Sagung Seto. Jakarta.

[SHCM] Student Health Center Manuals. 2013. Kirby Bauer antibiotic sensitivity [internet]. Tersedia di: http://shs-manual.ucsc.edu/policy/kirby-bauerantibiotic-sensitivity.

[WHO] World Health Organization. 2013. Diarrhoea: why children are still dying and what can be done [Internet]. Tersedia di: http://www.who.int/media centre/fact sheets/fs330/en/.

Yanarita, Naiem M, Budiadi and Sukarna. 2014. Development of the dayak ngaju community forest in the forest and peatland area, Central Kalimantan, Indonesia. IOSR Journal of Environmental Science, Toxicology and Food Technology (IOSR-JESTFT) 8(3):40-47.

Yani AP and Putranto AMH. 2014. Examination of the sungkai's young leaf extract (Peronema canescens Jack) as an antipiretic, immunity, antiplasmodium and teratogenity in mice (Mus.muculus ). International Journal of Science and Engineering (IJSE) 7(1):30-34.

Zhou Y, Zhu X, Hou H, Lu Y, Yu J, Mao L, Mao L and Sun Z. 2018. Characteristics of diarrheagenic Escherichia coli among children under 5 years of age with acute diarrhea: a hospital based study. BMC Infectious Diseases 18(63):110. 